The Agriculturists 11(1): 112-121 (2013) ISSN 2304-7321 (Online), ISSN 1729-5211 (Print)

A Scientific Journal of Krishi Foundation

\title{
Rice Ecosystem, Allelopathy and Environment - A Review
}

\author{
A. B. Siddique ${ }^{1 *}$ and B. S. Ismail ${ }^{2}$ \\ ${ }^{1}$ Senior Assistant Secretary, IMED, Ministry of Planning, Bangladesh. \\ ${ }^{2}$ Professor, School of Environmental \& Natural Resource Sciences, Universiti Kebangsaan \\ Malaysia 43600 UKM, Bangi Selangor, Malaysia. \\ *Corresponding author and Email: razia_abubakar@yahoo.com
}

Received: 22 April $2013 \quad$ Accepted: 18 May 2013

\begin{abstract}
Allelopathy is an important factor which contributes in determining distribution of species and their abundance within communities. Plant-plant interference is the combined effect of allelopathy, resource competition, and many other factors. Weed infestation is a major problem limiting the growth and yield of rice. Synthetic herbicide has been used for over 50 years as the prime source of weed control. The repeated use of herbicides in rice has already led to the evolution of resistance in some weed species. The conventional synthetic herbicides are becoming less effective against the resistant weed biotypes. Due to increase in the number of herbicide-resistant weeds and environmental concerns in the use of synthetic herbicides, allelopathy has been gaining preference as one of the considerable efforts in designing alternative weed management strategies. Modern ecotoxicologists and allelopathy researchers have been trying to identify allelochemicals to use as biodegradable pesticide. Two allelochemicals have been discovered, namely hexanedioic acid dioctyl ester and di-n-octyl phthalate which can be used as biopesticide. However, still there is enough scope to conduct such research that will contribute to protect our environment as well as increase food safety.
\end{abstract}

\section{Key words: Allelopathy, rice eco-system, allelochemical, environment}

\section{Introduction}

Rice is the main food crop and primary source of food for more than half of the world's population. More than $90 \%$ of the world's rice is grown and consumed in Asia where $60 \%$ of the earth's people live. Rice accounts for $30-75 \%$ of the calories consumed by more than 3 billion Asians. It is planted on about 154 million hectares annually or on about $11 \%$ of the world's cultivated land. According to United Nations (UN) estimation, the world population will grow from 6 billion in 2000 to 8 billion in 2030 . Therefore, $40 \%$ more rice is to be produced by 2030 to satisfy the growing demand without affecting the resource base adversely (Khush, 2005).
Weed infestation is a major problem limiting the growth and yield of rice (Bhatt and Tewari, 2006). In rice, the loss of yield due to weed infestation is greater than the combined yield losses caused by insect pests and diseases (Isley, 1960). In Asia, yield losses due to uncontrolled weed growth in direct seeded lowland paddy was $45-75 \%$, and for transplanted lowland paddy approximately 50\% (Johnson, 1996). Weed infestation causes a $10-35 \%$ reduction in grain yield in Malaysia (Karim et al., 2004). Nearly $12 \%$ of the total loss of crop yields has been attributed to the weeds alone (Anaya, 1999). Weed plants may affect the growth of crop plants either by competition for nutrients, water, space and light (Zimdahl, 1980) or by allelopathy 
(Rice, 1984). In the field, both allelopathy and competition usually act simultaneously.

In rice cultivation control of weeds is one of the important means of increasing crop yield. In all rice ecosystems, herbicides have become one of the most important components in weed control. There may be two reasons for increased use of herbicides: the first being the widespread adoption of high-yielding varieties which created economic incentives for farmers to reduce weed infestation; and the second is the availability of cheaper herbicides, indicating that the cost of weed control by herbicides in wet-seeded rice is less than one-fifth of the cost of a single handweeding (Moody, 1991). But the repeated use of herbicides in rice to control weed has already led to the evolution of resistance in some weed species to several herbicides in several countries (Watanabe et al., 1997). The conventional synthetic herbicides are becoming less and less effective against the resistant weed biotypes. Thirty weed species associated with rice have been evolved as resistance to herbicides globally, including the most widely used compounds such as propanil, 2, 4-D and some of the sulfonylureas (Valverde et al., 2000). Herbicide-resistant weeds pose the greatest threat to farmers when there are few or no other alternatives to control them (Heap, 2011). Due to increase in the number of herbicide-resistant weeds and environmental concerns in the use of synthetic herbicides, allelopathy has been gaining preference as one of the considerable efforts in designing alternative weed management strategies.

\section{Allelopathy and agriculture}

Weeds interfere crop growth and reduce yields, deteriorate crop quality, clog waterways and cause health problems; with eradication costs being massive (Singh et al., 2003). About 240 weeds have been reported to have allelopathic potential (Qasem and Foy, 2001), although many of these species have been tested with unrealistic bioassays (Inderjit and Keating, 1999). On the other hand, allelopathic crops that are able to chemically interfere with weed growth have also been identified, such as Secale cereale (rye) (Haramoto and Gallandt, 2004), Triticum aestivum (wheat) (Labbafi et al., 2010), Oryza sativa (rice) (Fang et al., 2013), Helianthus annus (sunflower) (Nikneshan et al., 2011) and Glycine max (Soyabean) (Mahmoodzadeh and Mahmoodzadeh, 2013). In addition to beneficial chemical interference of crops with weed growth, there is potential for the advantageous use of allelopathy for practices such as crop rotation, cover and smothers crops and retention of crop residues (Singh et al., 2003).

According to Duke et al. (2002), two approaches for utilization of allelopathy in crops to increase weed suppression are possible: a) to enhance the existing allelopathic potential of a particular crop and b) to introduce allelopathic potential through the insertion of foreign genes encoding for allelochemicals. This can be achieved through employing conventional breeding as well as genetic modification techniques. With increased environmental awareness and public pressure, less detrimental means of weed control are continually being sought. One such approach is to consider allelochemicals as a new source of herbicides. This approach may be beneficial as natural plant products which have advantage over synthetic herbicides. The benefits are many: a) allelochemicals often possess complex structures and exhibit structural diversity, making them valuable lead compounds, b) the compounds have molecular weight with little or no halogens or heavy atoms, c) allelochemicals have little environmental impacts as they degrade rapidly in the environment, and d) allelochemicals have novel target sites very often different to those of synthetics (Duke et al., 2002; Singh et al., 2003).

\section{Weed allelopathy}

A total of 240 weeds have been reported to have allelopathic potential (Qasem and Foy, 2001). Since weeds are a major cause of yield losses, the aggressive growth habits of some of the most tenacious species have come in for scrutiny. 
Putnam and Weston (1986) listed 90 weed species that showed allelopathic potential. It has been reported that some of the world's worst weeds contain allelochemicals including parthenium (Parthenium hysterophorus) (Nath, 1988), quackgrass [Elytrigia repens (L.) (Putnam and Weston, 1986), Johnsongrass (Sorghum halepense (Abdul- Wahab and Rice, 1967), Canada thistle (Cirsium arvense) (Stachon and Zimdahl, 1980) and giant foxtail (Setaria faberi) (Bell and Koeppe, 1972). The most investigations on weeds have tried fieldbased evidence with a search for allelochemicals. Parthenium hysterophorus, a tropical weed endemic to America, has done great damage to human, livestock and crops since arriving as an exotic to the Indian landscape and other places.
Numerous reports of the last two decades documented the phytotoxicity of its living and decomposing tissue, leachates, and root exudates (Forzwa and Karim, 2009). Recently, Ismail and Siddique (2012a, 2010(a), 2010(b); Siddique and Ismail $(2010,2009)$ reported that common rice field weeds i.e Fimbristylis miliacea, Cyperus iria, Echinochloa colona and Sphenoclea zeylanica showed growth inhibitory effects on the rice plants. Four common weeds grown in rice fields showed their allelopathic potential on paddy rice of Tarom variety in Pakistan (Alamdari and Deokule, 2009) (Table 1). Due to genetic variation, different rice verities responded differently (Table 2 and Figure 1) to the phytotoxic effect of Cyperus iria (Ismail and Siddique, 2011).

Table 1. Effect of whole plant leachates of studied weeds on growth parameters of paddy rice of Tarom variety (Alamdari and Deokule, 2009)

\begin{tabular}{|c|c|c|c|}
\hline \multirow{2}{*}{$\begin{array}{l}\text { Whole plant } \\
\text { leachates of } \\
\text { studied weeds }\end{array}$} & \multicolumn{3}{|l|}{ Growth parameters } \\
\hline & $\begin{array}{l}\text { Total number of tillers } \\
\text { pot }^{-1}\end{array}$ & Plant height $(\mathrm{cm})$ & $\begin{array}{l}\text { Elongation of flag leaf } \\
(\mathrm{cm})\end{array}$ \\
\hline Cyperus difformis & $17.11 \pm 1.57 a$ & $103.76 \pm 13.67 a$ & $21.89 \pm 3.04 a$ \\
\hline Echinochloa crusgalli & $14.45 \pm 0.69 a$ & $97.29 \pm 5.55 a$ & $22.22 \pm 0.75 a$ \\
\hline Paspalum paspaloides & $15.56 \pm 1.17 a$ & $99.80 \pm 9.20 a$ & $25.41 \pm 2.58 a$ \\
\hline Sagittaria trifolia & $16.44 \pm 1.17 a$ & $94.75 \pm 5.75 a$ & $22.36 \pm 1.55 a$ \\
\hline Control & $16.44 \pm 1.17 a$ & $100.72 \pm 3.02 a$ & $24.23 \pm 2.85 a$ \\
\hline Mean & $16.02 \pm 1.66$ & $99.26 \pm 7.70$ & $23.22 \pm 2.42$ \\
\hline
\end{tabular}

* Mean ( \pm ) Standard deviation and groups based on Duncan's Univariate comparison with $95 \%$ confidence intervals $(n=3)$.

Table 2. Effect of the debris of $C$. iria, on plant height, seedling fresh and dry weight (\% of control) of 5 rice varieties (Ismail and Siddique, 2011)

\begin{tabular}{|c|c|c|c|c|c|c|c|c|}
\hline \multicolumn{9}{|c|}{ Debris concentration } \\
\hline \multirow{2}{*}{$\begin{array}{l}\text { Rice } \\
\text { varieties }\end{array}$} & Control & Quarter & Half & Full & Control & Quarter & Half & Full \\
\hline & \multicolumn{4}{|c|}{ Plant height } & \multicolumn{4}{|c|}{ Fresh weight } \\
\hline MR211 & $100.0^{\mathrm{a}}$ & $81.8^{b}$ & $72.8^{b}$ & $69.7^{b}$ & $100.0 \mathrm{a}$ & $74.7^{\mathrm{b}}$ & $73.5^{b}$ & $67.5^{\mathrm{b}}$ \\
\hline MRQ74 & $100.0^{\mathrm{a}}$ & $85.0^{\mathrm{b}}$ & $71.7^{\mathrm{c}}$ & $67.0^{\mathrm{d}}$ & $100.0 \mathrm{a}$ & $73.1^{\mathrm{b}}$ & $64.6^{\mathrm{b}}$ & $66.9^{\mathrm{b}}$ \\
\hline MR220 & $100.0^{\mathrm{a}}$ & $80.8^{\mathrm{b}}$ & $74.4^{\mathrm{b}}$ & $73.5^{\mathrm{b}}$ & $100.0 \mathrm{a}$ & $72.9^{b}$ & $66.0^{\mathrm{b}}$ & $63.6^{\mathrm{b}}$ \\
\hline MR84 & $100.0^{\mathrm{a}}$ & $68.1^{\mathrm{b}}$ & $66.8^{\mathrm{b}}$ & $66.8^{\mathrm{b}}$ & $100.0 \mathrm{a}$ & $70.4^{\mathrm{b}}$ & $62.4^{\mathrm{bc}}$ & $57.1^{\mathrm{c}}$ \\
\hline MR232 & $100.0^{\mathrm{a}}$ & $65.0^{\mathrm{b}}$ & $65.2^{\mathrm{b}}$ & $58.9^{c}$ & $100.0 \mathrm{a}$ & $59.1^{\mathrm{b}}$ & $53.1^{\mathrm{b}}$ & $47.0^{\mathrm{c}}$ \\
\hline
\end{tabular}

Means within rows followed by same letter are not significantly different $\left(\mathrm{p}>0.05, \mathrm{LSD}_{0.05)}\right.$ 


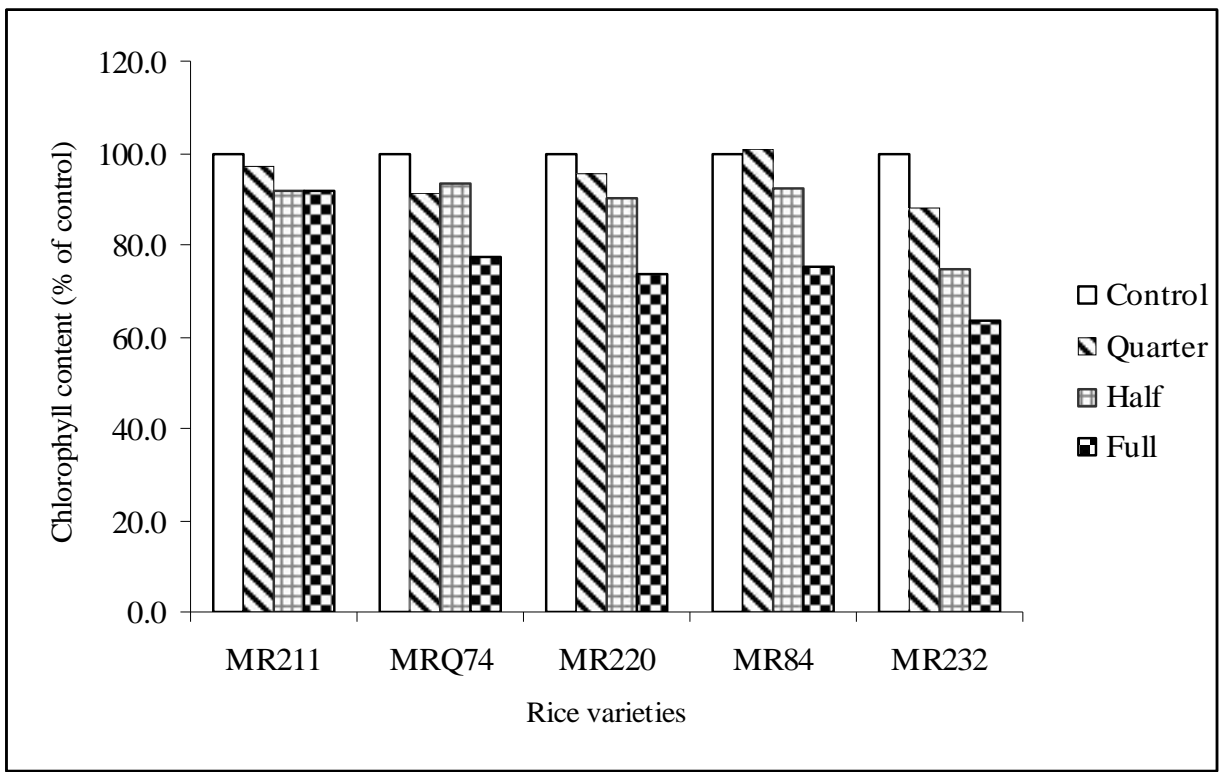

Fig. 1. Inhibitory effect of the debris of $C$. iria on leaf chlorophyll content (\% of control) of five rice varieties (Ismail and Siddique, 2011)

\section{Allelopathy in rice}

To establish an alternative strategy for weed management in rice, the phenomenon allelopathy has been a subject of continued research for a long time (Olofsdotter, .2001; Takeuchi et al., 2001) and already a large number of rice varieties have been found to suppress several weed species when grown together under field and laboratory condition (Dilday et al., 1998; Olofsdotter et al., 1999; Azmi et al., 2000). The first observation of rice was made in field examination in Arkansas, USA where about 191 of 5,000 rice accessions inhibited the growth of ducksalad weed (Heteranthera limosa) (Dilday et al., 1989) which led to a further large screening program. USA-ARS have screened more than 16,000 rice accessions from 99 countries and 412 rice accessions have shown the allelopathic potentiality against Ammonia coceinea (Dilday et al., 1998). Dilday et al. (1998) evaluated the phytotoxic effects of 12,000 and 5000 rice accessions against ducksalad (Heteranthera limosa) and red stem (Spinacia oleracea), respectively. Several field screening was made in different countries such as Egypt, Korea, Japan, India, Thailand, Malaysia and United States (Dilday et al., 1998). In Egypt, more than 40 out of 1000 (were screened) rice varieties showed inhibitory activity with Echinochloa crusgalli and Cyperus difformis (Hassan et al., 1998) and suggested that genetic variations is the main factor to environment. Salam and Noguchi (2009) reported that the rice variety BR17 is the most allelopathic among 102 Bangladesh rice cultivars. Water extract of rice in different concentrations showed different degree of allelopathic inhibition on wheat, radish and lettuce (Tareak, 2010) (Table 3). 
Table 3. Effect of six rice straw extract concentrations on seedling root growth of four plant species/cultivars over time (Tareak, 2010)

\begin{tabular}{|c|c|c|c|c|c|c|c|c|c|c|c|}
\hline \multirow{3}{*}{$\begin{array}{l}\text { Conc. } \\
(\mathrm{g} \quad 500 \\
\mathrm{mL}^{-1} \\
\left.\mathrm{H}_{2} \mathrm{O}\right)\end{array}$} & \multicolumn{6}{|c|}{ Wheat (Triticum aestivum) } & \multirow{2}{*}{\multicolumn{3}{|c|}{$\begin{array}{l}\text { Radish } \\
\text { (Raphanus sativus) }\end{array}$}} & \multirow{2}{*}{\multicolumn{2}{|c|}{$\begin{array}{l}\text { Lettuce } \\
\text { (Lactuca } \\
\text { sativa) }\end{array}$}} \\
\hline & \multicolumn{3}{|c|}{ Sakha 61} & \multicolumn{3}{|c|}{ Sakha 94} & & & & & \\
\hline & $72 \mathrm{~h}$ & $96 \mathrm{~h}$ & $120 \mathrm{~h}$ & $72 \mathrm{~h}$ & $96 \mathrm{~h}$ & $120 \mathrm{~h}$ & $72 \mathrm{~h}$ & $96 h$ & $120 \mathrm{~h}$ & $120 \mathrm{~h}$ & $144 \mathrm{~h}$ \\
\hline 20 & 51.9 & 61.3 & 67.5 & 35.2 & 31.4 & 23.9 & 45.6 & 34.1 & 33.9 & 23.2 & 5.4 \\
\hline 30 & 51.9 & 52.1 & 56.5 & 31.5 & 19.6 & 9.2 & 36.8 & 23.5 & 32.7 & 0.0 & 0.0 \\
\hline 40 & 37.9 & 52.3 & 59.1 & 25.4 & 17.5 & 12.5 & 0.0 & 23.5 & 35.6 & 0.0 & 0.0 \\
\hline 50 & 23.8 & 30.5 & 59.7 & 21.9 & 13.2 & 7.1 & 0.0 & 5.8 & 11.0 & 0.0 & 0.0 \\
\hline 70 & 14.4 & 31.7 & 47.3 & 19.8 & 13.5 & 7.0 & 0.0 & 6.3 & 11.1 & 0.0 & 0.0 \\
\hline Control & 100 & 100 & 100 & 100 & 100 & 100 & 100 & 100 & 100 & 100 & 100 \\
\hline LSD 0.05 & 15.1 & 22.7 & 21.1 & 7.5 & 6.8 & 7.1 & 8.8 & 11.0 & 10.6 & 1.8 & 1.8 \\
\hline
\end{tabular}

Values are expressed as a \% of the control.

International Rice Research Institute (IRRI) developed a laboratory method for screening whole- plant-bioassay or allelopathic rice screening (Navarez and Olofsdotter, 1996) to eliminate the effects of competitive interference for resources between rice and test plants. Interestingly using this method, inhibitory activity of 111 rice varieties in Philippines has been shown to be inconsistent between laboratory and field trials (Olofsdotter et al., 1999). However, in both laboratory screening and field experiments revealed that rice allelopathy is active in both monocot and dicot weeds (Dilday et al., 1991; Fuji 1994; Olofsdotter and Navarez, 1996; Hasan et al., 1998; Kim and Shin, 1998). Laboratory screening for allelopathy study in rice have also been undertaken and it has been found that there was no mark difference among rice varieties for weed species inhibition activity (Fuji, 1994; Hasan et al., 1998; Azmi et al., 2000) suggesting that different rice cultivars are capable to supress particular weed species.

\section{Rice allelochemicals}

The exploiting research for isolating and identifying rice allelochemicals has started but yet not yielded chemicals that could exert allelopathic effect (Rimando et al., 2001). Several studies have been conducted by various researchers to identify allelochemical(s) from rice and to find their allelopathic potential (Chung et al., 2001; Kim and Kim, 2002; Rimando et al., 2001; Kong et al., 2004; Seal et al., 2004a). Among them Seal et al. (2004a) found 200 different compounds in rice root exudates which fall under three main chemical classes such as phenolics, phenylalkanoic acids and indoles. Several classes of secondary metabolites determined from the root exudates of rice like phenolics (Jung et al., 2001; Kim and Kim, 2002; Rimando et al., 2001; Olofsdotter et al., 2002; Inderjit et al., 2002; Seal et al., 2004b), alkyl resocinols (Bouillant et al., 1994), momilactone B (Kato-Noguchi and Ino, 2005; Kong et al., 2004), amino acids (Bacillo_Jimenez et al., 2003) and flavones (Kong et al., 2004). Several studies focused that common putative allelochemicals found in rice are phenolic acid compounds (Chou et al., 1991; Inderjit 1996; Blum, 1998) such as p-coumaric acid, p-hydrobenzoic acid, ferulic acid and vanillic acid. Nontheless, it is belived that phenolics must play an important role for rice allelopathy. So, identifying allelochemical in rice is an important issue for understanding allelopathy mechanism. 
A large number of rice varieties were found to inhibit the growth of several plant species when the rice varieties were grown together with the plants under field and/or laboratory conditions (Dilday et al., 1998; Hassan et al., 1998; Olofsdotter et al., 1999). These findings suggest that living rice may produce and release allelochemical(s) into the neighboring environment. A number of secondary metabolites, phenolic acids, phenylalkanoic acids, hydroxamic acids, fatty acids, terpenes and indoles were identified in rice extracts (Rimando and Duke, 2003). These compounds are ubiquitous in plants and some of these compounds have growth inhibitory activity against several plant species. It is not clear, however, whether these compounds are released from living rice plants into the neighboring environment, and act as allelochemicals in natural ecosystems. In addition, it was found that there was no significant correlation between the level of growth inhibitory substances in plants and their level in the root exudates (Wu et al., 2001). It was found that the growth of soybean callus was inhibited by rice callus when both callus tissues were incubated together (Yang and Futsuhara, 1991). Zhang et al. (2005) identified potent allelopathic rice germplasm for breeding new rice varieties with allelopathic potential. Yiqing et al. (2005) focussed on the evaluation of allelopathic wild rice species germplasm resources for barnyardgrass control. He et al. (2006) detected the diethyl ether extracts from the root exudates of two rice accessions, allelopathic rice (PI312777) and non-allelopathic rice (Lemont) seedlings. The individual compounds were identified by comparing their mass spectra with those from NIST and Wiley Library of mass spectral database. Sixty-three compounds were detected in root exudates of PI312777 and 77 compounds in Lemont. The substances were terpenoids, phenols (quinones), aldehydes (ketones), heterocyclic alcohols, ethers, hydrocarbons etc. (He et al., 2006). Hiroshi (2008) examined the effect of husk extracts of wild rice spp. on root and shoot growth of lettuce, barnyard grass and Eclipta thermalis (false daisy). The results suggested that the husk extracts of Oryza glumaepatula contain water soluble allelochemicals that inhibit root growth of lettuce but promote shoot growth of false daisy. Ethyl acetate soluble allelochemicals that inhibit root growth of barnyard grass. Olofsdotter et al. (1995) described the assessment of the allelopathic potential of root exudates from rice plants during their early developmental stage and allelopathic potential of rice leaching by using Petri dish bioassay under laboratory condition.

\section{Conclusions}

Despite the tremendous growth in allelopathy research in recent years there are lots of areas that have yet not been studied. Isolation and identification of rice allelochemicals are important to toxicological and eco-toxicological studies before crossing between present traits and commercial germplasm. Agronomic managements of rice like date of sowing, seeding depth, standing water depth, amount and type of fertilizers, duration of dry period, density and species of weeds are to be investigated for rice based allelopathy. Using allelopathic potential, rice cultivars in crop rotation and as companion crop need to be studied. Some rice cultivars are showing residual allelopathic effects on weed emergence as they contain acid during their decomposition. In paddy field, many weed species are either completely inhibited or significantly reduced by rice allelopathic potential. Eeveral studies have focused that the allelopathic materials on weed species are selective. Therefore, sensitive weeds are to be evaluated for their seed moisture content, growing habit, survival capability and extend of competitive ability against rice for natural weed management. So, to understand rice-weed chemical interaction, detail researches are needed with a long term vision.

\section{References}

Abdul-Wahab, A. S. and Rice, E. L. 1967. Plant inhibition by Johnson grass and its possible significance in old-field 
Siddique and Ismail /The Agriculturists 11(1): 112-121 (2013)

succession. Bull. Torrey Bot. Club, 94: 486-497.

Alamdari, E. G and Deokule, S. S. 2009. Allelopathic effects of some weeds on growth and yield of paddy rice (Tarom variety) in northern Iran. Pak. J. Weed Sci. Res. 15 (2-3): 123-12.

Anaya, A. L. 1999. Allelopathy as a tool in the management of biotic resource in agroecosystems. Crit. Rev. Plant Sci. 18: 697-739.

Azmi M, Abdullah M. Z. and Fujii, Y. 2000. Exploratory study on allelopathic effect of selected Malaysian rice varieties and rice field weed species. J. Trop. Agri. Food Sci. 28: 39-54.

Bacilio-Jimenez, M., Aguilar-Flores, S., Ventura-Zapata, E., Perez-Campos, E., Bouquelet, S. and Zenteno, E. 2003. Chemical characterization of root exudates from rice (Oryza sativa) and their effects on the chemotactic response of endophytic bacteria. Plant Soil, 249 : 271-277.

Bell, D. T. and Koeppe, D. E. 1972. Noncompetitive effects of giant foxtail on the growth of corn. Agron. J. 64: 321-325.

Bhatt, M. D. and Tewari, A. 2006. Loss in growth and yield attributes due to weed composition in transplanted paddy in Terai region. Sci. World. 4(4): 99-101.

Blum, U. 1998. Effects of microbial utilization of phenolic acids and their phenolic acid breakdown products on allelopathic interactions. J. Chem. Ecol. 24: 685-708.

Bouillant, M. L., Jacoud, C., Zanella, I., FavreBonvin, J. and Vally, R. 1994. Identification of 5- (12-heptadecenyl)resorcinol in rice root exudates. Phytochemistry, 35: 769-771.

Chou, C. H., Chang, F. J. and Oka, H. I. 1991. Allelopathic potential of wild rice Oryza perennis. Taiwania, 36 (3): 201-210.

Chung, I. M., Ahn, J. K. and Yun, S. J. 2001. Identification of allelopathic compounds from rice (Oryza sativa L.) straw and their biological activity. Can. J. Plant Sci. 81: 815-819.

Dilday, R. H., Nastasi, P. and Smith, R. J. Jr. 1989. Allelopathic observations in rice (Orzya sativa L.) to ducksalad (Heteranthera limosa). Proceedings of the Arkansas Academy of Science, 43: 21 22.

Dilday, R. H., Yan, W. G., Moldenhauer, K. A. K. and Gravois, K. A. 1998. Allelopathic activity in rice for controlling major aquatic weeds. In Olofsdotter, M., ed. Allelopathy in Rice. Manila, Philippines: Int. Rice Research Institute. 7-26 pp.

Dilday, R. H., Nastasi, P., Lin, J. and Smith, R. J., Jr. 1991. Allelopathic activity in rice (Oryza sativa L.) against ducksalad (Heteranthera limosa (sw.) Willd.). In D. Hanson,M.J. Shaffer. D. A. Ball. and C.V. Cole., eds. Symposium Proc. on Sustainable Agriculture for the Great Plains. USDA, ARS-89. 193-201 pp.

Duke, S. O., Dayan, F. E., Rimando, A. M., Scrader, K. K., Aliotta, G., Olivia, A. and Romangi, J. G. 2002. Chemicals from nature for weed management, Weed Sci. 50: 138-151.

Fang, C., Zhuang, Y., Xu, T., Li, Y., Li, Y. and Lin, W. 2013. Changes in rice allelopathy and rhizosphere microflora by inhibiting rice phenylalanine ammonialyase gene expression. J. Chem. Ecol.. 39(2): 204-12.

Forzwa, R. and Karim, S. M. R. 2009. Allelopathic effects of aqueous extracts of parthenium weed on the seed germination and growth of field crops. Abstracts, Annual conference of Bangladesh Botanical Society, held at Chittagong University, 16-17 pp.

Fujii, Y. 1994. The potential biological control of paddy weeds with allelopathyallelopathic effect of some rice cultivars. Proceedings of the International Symposium on Biological Control and Integrated Management of Paddy and Aquatic Weeds, 1992. Tsukuba, Japan, 305-320 pp. 
Haramoto, E. R. and Gallandt, E. R. 2004. Brassica cover cropping for weed management: A review. Renewable Agriculture and Food Systems 19:187198.

Hassan, S. M., Aidy, I. R., Bastawisi, A. O. and Draz, A. E. 1998. Weed management using allelopathic rice varieties in Egypt. In 'Allelopathy in Rice'. (Ed. M Olofsdotter, International Rice Research Institute: Manila, 27-37 pp.).

Heap, I. M. 2011. International Survey of Herbicide Resistant Weeds, http://www.weedscience.org/in.asp (15 January 2011).

He, H. B., Lin, W. X., Wang, H. B., Fang, C. X. and Liang, Y. Y. 2006. Analysis of metabolites in root exudates from allelopathic and non allelopathic rice seedlings. Allelopathy J. 18: 247254.

Hiroshi, N. 2008. Effects of husk extracts of wild rice spp. on seedling growth of lettuce, barnyard grass and Eclipta thermalis. Allelopathy J. 22: 391-396.

Inderjit and Keating K. I. 1999. Allelopathy: principles, procedures, processes, and promises for biological control. Adv. Agron. 67: 141-231.

Inderjit., Streibig, J. C. and Olofsdotter, M. 2002. Joint action of phenolic acid mixtures and its significance in allelopathy research. Physiol. Plant. 114: 422-428.

Inderjit. 1996. Plant phenolics in allelopathy. Bot. Rev. 62: 186-202.

Isley, D. 1960. Weed Identification and Control in North Central States. Iowa State Univ. Press. Ames. Iowa, USA. 28-39 pp.

Ismail, B. S. and Siddique, A. B. 2010(a). Allelopathic Effects of Echinochloa colona On The Growth Of The Rice Plant. Proc. of The 16th Asian Agricultural Symposium (AAS) and 1st International Symposium on Agriculture Technology (ISAT), 25-27
August 2010, Bangkok, Thailand, 429-431 pp.

Ismail, B. S. and Siddique, A.B. 2010(b). Phytotoxic Effects of the Aqueous Extracts of Ludwigia hysopifolia on the Growth of Rice Seedlings. Proceedings of The International Seminar on Weed Management in Indonesia, November, 2010. Bandung, Inonesia, 9-11 pp.

Ismail, B. S. and Siddique, A. B. 2011. The Inhibitory Effect of Grasshopper's Cyperus (Cyperus iria $\quad$ L.) on the Seedling Growth of Five Malaysian Rice Varieties. Trop. Life Sci. Res. 22(1): 8189.

Ismail, B. S. and Siddique, A. B. 2012a. Allelopathic Inhibition by Fimbristylis miliacea on the Growth of the Rice Plants. Adv. Envr. Biol. 6(8): 2423-2427.

Ismail, B. S. and Siddique, A. B. 2012b. Identification of allelochemicals from Fimbristylis miliacea and their allelopathic potential against weed species. Allelopathy J, 30(2): 311-318. .

Johnson, D. E. 1996. Weed Management in Small Holder Paddy Production in the Tropics. Available: http://ipmworld.umn.edu/hapters/Johnson. htlm. 20 July 2010.

Jung, I. M., Ahn, J. K. and Yun, S. J. 2001. Assessment of allelopathic compounds from rice (Oryza sativa L.) straw and their biological activities. Can. J. Plant Sci.81: 815-819.

Karim, S. M. R., Azmi, M. and Ismail, B.vS. 2004. Weed problems and their management in rice fields of Malaysia: An overview. Weed Biol. Manag. 4:177-186.

Kato-Noguchi, H. and Ino, T. 2005. Possible involvement of momilactone $\mathrm{B}$ in rice allelopathy. J. Plant Physiol. 162: 718721.

Khush, G.S. 2005. What it will take to feed 5.0 Billion consumers in 2030. Plant Mol. Biol. 56: 1-6. 
Kim, J. T. and Kim, S. H. 2002. Screening of allelochemicals on barnyard grass (Echinochloa crus-galli) and identification of potentially allelopathic compounds from rice (Oryza sativa) variety hull extracts. Crop Prot. 21: 913920.

Kim, K. U. and Shin, D. H. 1998. Rice allelopathy research in Korea. p. 39-44. In M. Olofsdotter (ed.) Proc. of the Workshop on Allelopathy in Rice.Manila, Philippines. 25-27 Nov. 1996. Int. Rice Res. Inst., Makati City, Philippines.

Kong, C., Liang, Xu, W., Xu, X. and Hu, F. 2004. Release and activity of allelochemicals from allelopthic rice seedlings. J. Agril. Food Chem. 52: 2861-2865.

Labbafi, M. R., Hejazi, A., Maighany, F., 2, Khalaj, H. and Ali Mehrafarin, A. 2010. Evaluation of allelopathic potential of Iranian wheat (Triticum aestivum L.) cultivars against weeds. Agri. Bio. J. North Amer. 1(3): 355-361.

Mahmoodzadeh, $\mathrm{H}$. and Mahmoodzadeh, M. 2013. Allelopathic potential of soybean (Glycine $\max$ L.) on the germination and root growth of weed species. Life Sci. J. 10(5): 63-69.

Moody, K. 1991. Weed management in rice. In Handbook of Pest Management in Agriculture. $2^{\text {nd }}$ edition. Pimenteal, D. ed. CRC Press Boca Raton, Florida, USA. 301-328 pp.

Nath, R. 1988. Parthenium hysterophorus a review. Agric Review. 9: 171-179.

Navarez, D. and Olofsdotter, M. 1996. Relay seeding procedure as screening method in allelopathy research. Proc. 2nd Int. Weed Control Conf. 4: 285-1290.

Nikneshan, P., Karimmojeni, H., Moghanibashi, M. and Nayereh al sadat Hosseini. 2011. Allelopathic potential of sunflower on weed management in safflower and wheat Australian J. Crop Sci. 5(11): 1434-1440.
Olofsdotter M., Navarez D., Rebulanan, M. and Streibig, J. C. 1999. Weed-suppressing rice cultivars does allelopathy play a role? Weed Res. 39: 441-454.

Olofsdotter, M., Rebulanan, M., Madrid, A., Dali, W., Navarez, D. and Olk, D. C. 2002. Why phenolic acids are unlikely primary allelochemicals in rice. J. Chem. Ecol. 28: 229-242.

Olofsdotter, M. 2001. Getting closer to breeding for competitive ability and the role of allelopathy-an example from rice (Oryza sativa). Weed Tech. 15: 798-806.

Olofsdotter, M. and Navarez, D. 1996. Allelopathic rice in Echinochloa crus-galli control. p. 1175-1182. In H. Brown, et al. (ed.) Proc. of the 2nd Int. Weed Control Congress, Copenhagen, Denmark. 25-28 June 1996. DJF, Flakkebjerg, Denmark.

Olofsdotter, M., Navarez, D. and Moody, K. 1995. Allelopathic potential in rice (Oryza sativa L.) germplasm. Ann. Applied Biol. 127: 543-560.

Putnam, A. R. and Weston, L. A. 1986. Adverse impacts of allelopathy in agricultural systems. In The Science of Allelopathy (ed. A. R. Putnam and C. S. Tang), pp. 43-65. Wiley, New York.

Qasem, J. R. and Foy, C. 1. 2001. Weed allelopathy, its ecological impact and future prospects: a review. In: Allelopathy in Agroecosystems. R. K. Kohli, H.P. Singh and D. R. Batish. New York: Haworth Press, pp, 43-119.

Rice, E. L. 1984. Allelopathy. 2nd Edn. New York: Academic Press.

Rice, E. L. 1987. Allelopathy: an overview. In: G.R. Waller (Ed.), Allelochemical: Role in Agriculture and Forestry. American Chemical Society Symposium. 330: 8-22.

Rimando, A. M and Duke, S. O. 2003. Studies on rice allelochemicals. In 'Rice; Origin, History, Technology and Production'. (Eds. CW Smith, RH Dilday) pp. 221244, (John Wiley \& Sons, Inc.: Hoboken, New Jersey). 
Rimando, A. M., Olofsdotter, M., Dayan, F. E. and Duke, S. O. 2001. Searching for rice allelochemicals: An example of bioassayguided isolation. Agron J. 93: 16-20.

Salam, M. A. and Kato-Noguchi, H. 2009. Screening of Allelopathic Potential Bangladesh Rice Cultivars by DonorReceiver Bioassay. Asian J. Plant Sci. 8: 20-27.

Seal, A. N., Haig, T., and Pratley, J. E. 2004(b). Evaluation of putative allelochemicals in rice roots exudates for their role in the suppression of arrowhead root growth. J. Chem. Ecol. 30: 1663-1678.

Seal, A. N., Pratley, J. E., Haig, T., and An, M. 2004(a). Identification and quantitation of compounds in a series of allelopathic and non-allelopathic rice root exudates. $J$. Chem. Ecol. 30: 1647-1662.

Siddique, A. B. and Ismail, B. S. 2009. Assessment of Allelopathic Potential of Goose Weed (Sphenoclea eylanica) on Selected commonly used rice varieties in Malaysia. Prosiding Kolokium Siswazah Ke-9, Fakulti Sains dan teknologi, Ukm, Bangi. pp: 150- 152.

Siddique, A. B. and Ismail, B. S. 2010. Allelopathic Effects of Fimbristylis miliaceae on Rice Plants. . Proceedings of "The 16th Asian Agricultural Symposium (AAS) and 1st International Symposium on Agriculture Technology (ISAT)" Bangkok, Thailand, on 2527 August. 72-75 pp.

Singh, H. P., Batish, D. R. and Kohli, R. K. 2003. Allelopathic interactions and allelochemicals; New possibilities for sustainable weed management. Crit. Rev. Plant Sci. 22: 239-311.

Stachon, W. J. and Zimdahl, R. L. 1980. Allelopathic activity of Canada thistle (Cirsium arvense) in Colorado. Weed Sci. 28: 83-86.

Takeuchi, Y., Kawaguchi, S. and Yoneyama, K. 2001. Inhibitory and promotive allelopathy in rice (Oryza sativa L.). Weed Biol. Manag. 1: 147-156.
Tarek A, E. S. 2010. Rice straw as an allelopathic agent for controlling weeds. Seventeenth Australasian Weeds Conference. 26-30 September, 2010. 143$146 \mathrm{pp}$.

Valverde, B. E., Riches, C. R. and Caseley, J. C. 2000. Prevention and management of herbicide resistant weeds in rice. Published by Grafos, S. A., Cartago, Costa Rica. 25-30 pp.

Watanabe, H., Azmi, M. \& Ismail, M. Z. 1997. Emergence of major weeds and their population change in wet-seeded rice fields of the MUDA area, Peninsular Malaysia. In: Rajan, A. (ed.), Proc. 16th Asian Pacific Weed Science Society Conf. pp: 246-250. Kuala Lumpur, Malaysia.

Weston, L. A. 1996. Utilization of allelopathy for weed management in agroecosystems. Agron. J. 88: 860-866.

Wu, H., Haig, T., Pratley, J., Lemerle, D. and An, M. 2001. Allelochemicals in wheat (Triticum aestivum L.): Production and exudation of 2,4-dihydroxy-7methoxy-1,4- benzoxazin-3- one. J. Chem. Ecol. 27: 1691-1700.

Yang Y. S and Futsuhara, Y. 1991. Inhibitory effects of volatile compounds released from rice callus on soybean callus growth: allelopathic evidence observed using in vitro culture. Plant Sci. 77: 103-110.

Yiqing, G., Fudou, Z., Dayun, T., Liuqing, Y. and David, G. 2005. Preliminary studies on the allelopathic potential of wild Rice (Oryza) germplasm. Allelopathy J. 15: 13-20.

Zhang, Z., Zhou,Y., Lu, D. and Yu, L. 2005. Identification of allelopathic potential of Chinese rice (Oryza sativa L.) germplasm. Allelopathy J. 15: 111-118.

Zimdahl, R. L. (1980). Weed Crop Competition: A Review. International Plant Protection Centre; Oregon State University. (3rd March, 1990). 
